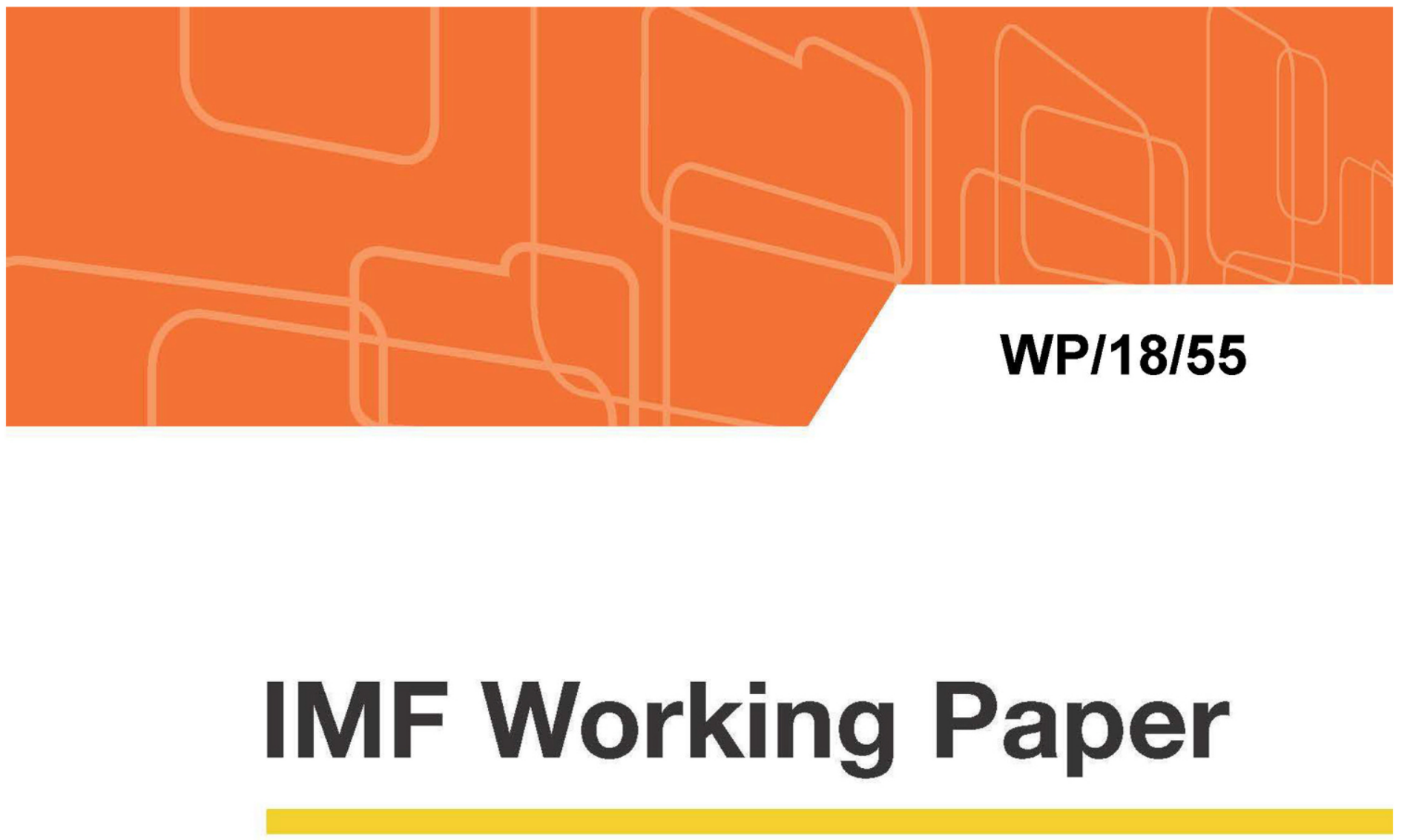

\title{
The Effective Lower Bound for the Policy Rate in Euroized Economies-An Application to the Case of Albania
}

by Guido della Valle, Erald Themeli, Romain Veyrune, Ezequiel Cabezon, and Shaoyu Guo

IMF Working Papers describe research in progress by the author(s) and are published to elicit comments and to encourage debate. The views expressed in IMF Working Papers are those of the author(s) and do not necessarily represent the views of the IMF, its Executive Board, or IMF management. 


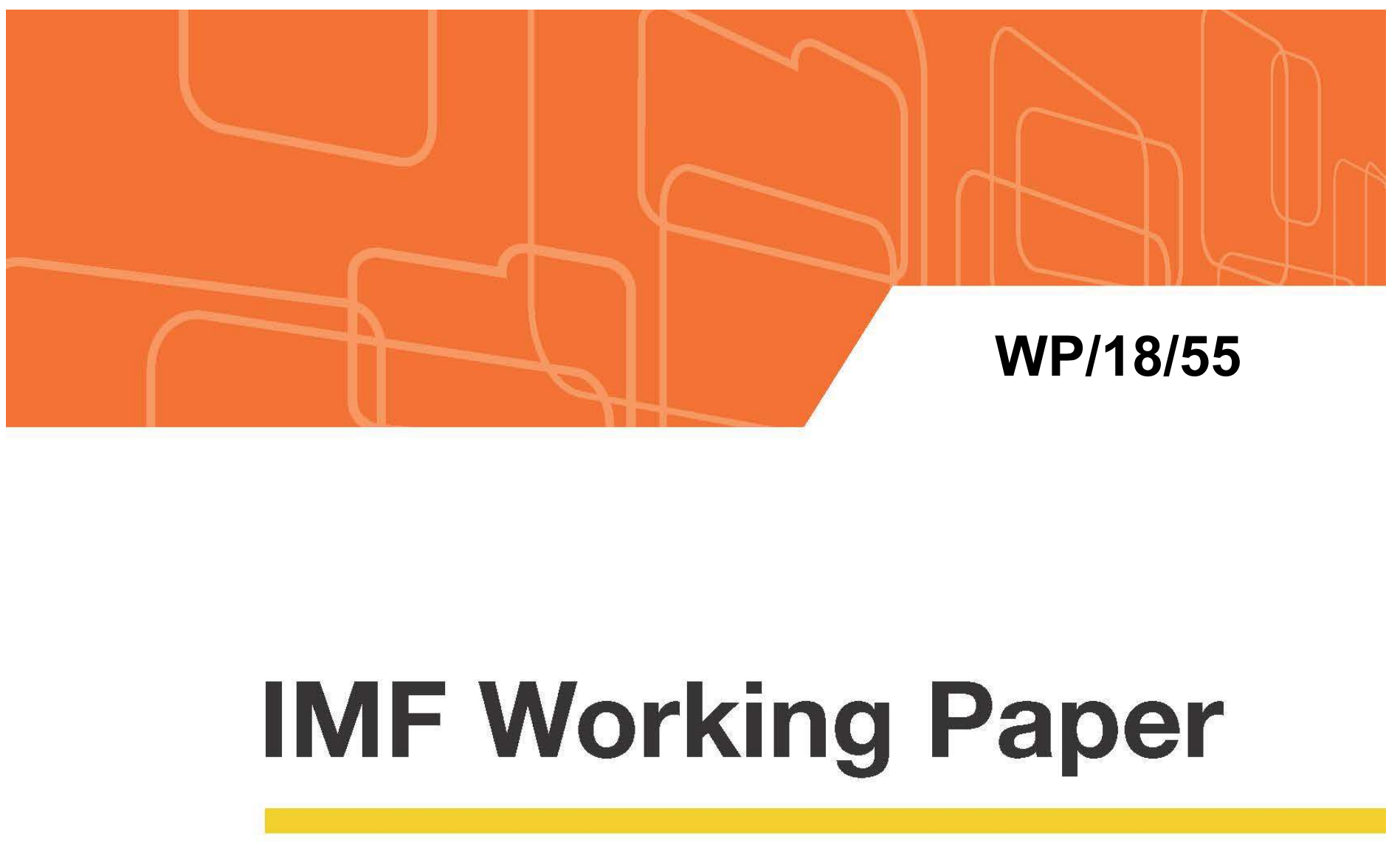

\section{The Effective Lower Bound for the Policy Rate in Euroized Economies-An Application to the Case of Albania}

by Guido della Valle, Erald Themeli, Romain Veyrune, Ezequiel Cabezon, and Shaoyu Guo

IMF Working Papers describe research in progress by the author(s) and are published to elicit comments and to encourage debate. The views expressed in IMF Working Papers are those of the author(s) and do not necessarily represent the views of the IMF, its Executive Board, or IMF management. 


\title{
IMF Working Paper
}

Monetary and Capital Markets Department

The Effective Lower Bound for the Policy Rate in Euroized Economies

An Application to the Case of Albania

Guido della Valle, Erald Themeli, Romain Veyrune, Ezequiel Cabezon, and Shaoyu Guo ${ }^{1}$

Authorized for distribution by Ghiath Shabsigh

March 2018

IMF Working Papers describe research in progress by the author(s) and are published to elicit comments and to encourage debate. The views expressed in IMF Working Papers are those of the author(s) and do not necessarily represent the views of the IMF, its Executive Board, or IMF management.

\begin{abstract}
Based on the experience of the Bank of Albania, the paper proposes a framework to estimate the interest rate lower bound in small, open, and euroized economies. The paper introduces a stylized monitoring tool to assess the unintended consequences of low policy rates. The paper is the first attempt to estimate the impact of low interest rate on the public's demand for banknote by denomination. A strong preference for banknotes leads economic agents to require a higher remuneration of banks' deposits, lifting the lower bound above zero. Financial euroization also lifts the lower policy bound due to the higher propensity of substituting domestic with foreign currency-denominated assets as a function of the interest rate differential. Policies aiming at reducing financial euroization contribute to bring down the lower bound.
\end{abstract}

JEL Classification Numbers: E52 (Monetary Policy).

Keywords: Monetary policy, interest rate lower bound, euroization, Albania.

Author's E-Mail Address: gdellavalle@imf.org; rveyrune@imf.org; ethemeli@bankofalbania.org.

\footnotetext{
${ }^{1}$ The authors would like to thank Simon Gray, Ananthakrishnan Prasad, Anita Tuladhar, and the participants of the conference "Negative Euro Area Interest Rates and Spillovers on Western Balkan Central Bank Policies and Instruments," Tirana, May 4-5, 2017 for their very useful comments. Shaoyu Guo ended his appointment with the IMF in January 2018.
} 


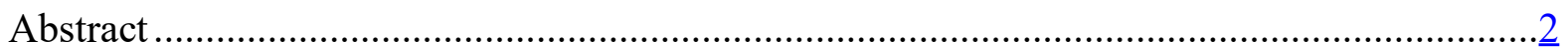

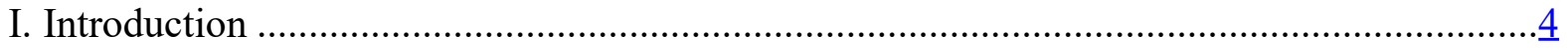

II. Determinants of the Technical Lower Bound .............................................................. $\underline{5}$

A. The Demand for Banknotes in Albania.............................................................

B. The Demand of Large Denomination Banknotes................................................

III. Determinants of the Effective Lower Bound ............................................................ 12

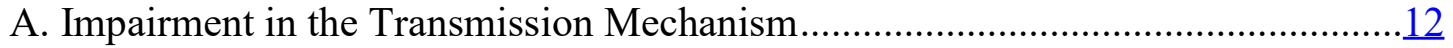

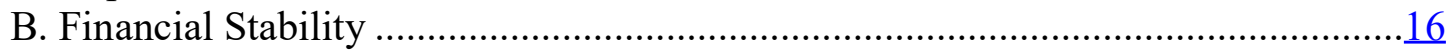

IV. Proposal for a Systematic Monitoring Framework ...............................................

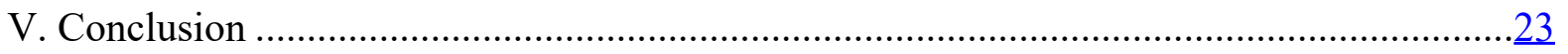

Tables

1. Estimates of the Demand of Banknotes ..................................................................

2. Estimates of Banknote Composition......................................................................11

Figures

1. Preference for Cash and Financial Depth in Albania and its Regional Peers ......................

2 Evolution of Cash to GDP and Cash to M3 ratio...............................................................

3. Share of Different Banknotes in Circulation ...............................................................

4. Deposit Rate and Policy Rate ...............................................................................

5. Risk-Free Yield Curve ......................................................................................

6. Monetary Policy Transmission in Euroized Economies .............................................

7. Non-performing loans in Euro and Lek ................................................................... 17

8. Albanian Banking System Net Interest Margin .................................................... 18

9. The Impact of Low Interest Rates on the Asset and Liabilities Structure of the Banking

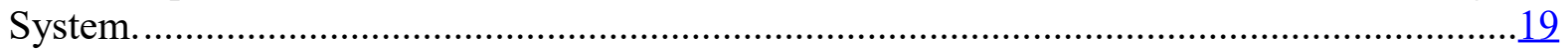

10. The Effective Lower Bound Barometer in Albania......................................................23

Boxes

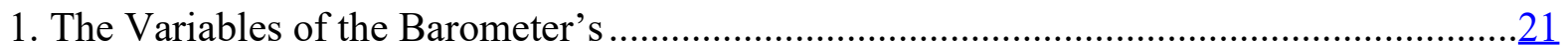

Appendixes

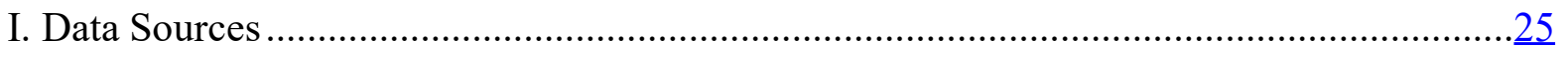




\section{INTRODUCTION}

In the context of inflation targeting and flexible exchange rate, Bank of Albania (BoA) has pursued an expansionary monetary policy to counteract subdued economic growth and belowtarget inflation. Reacting to a further bout of disinflation in the first quarter of 2016, the BoA cut the policy rate to a historical low of 1.25 percent in May 2016, with the deposit facility rate set at 0.25 percent and the marginal lending facility rate at 2.25 percent. A key policy question for the BoA has been how far policy rates could be further lowered as the policy rate reached its lowest level in Albania. The question was relevant while there were risks of further downside shocks to inflation and of dis-anchoring of inflation expectations.

The question of the lower policy rate bound becomes critical in the context of global low interest rates. Over the past 30 years, world real interest rates have been in secular decline (Broadbent 2014). Since the global financial crisis, interest rates have fallen further toward zero. A two percent inflation target would now put nominal interest rates at two percent on average over the cycle. Thus, the lower bound issue could regularly re-emerge in the future as there is materially less room above zero for monetary policy than there was a generation ago. It also remains relevant in Albania as inflation has recovered from the lows recorded in 2016 but remains distant from the 3 percent target.

While much work was dedicated to estimating the lower bound in the advanced economies that introduced negative policy rates, less was done for small, open, and euroized economies with strong economic and financial links to the euro area. The paper introduces a framework according to which the lower bound for the policy rate in these countries could be empirically assessed. The methodology presented in this paper has been developed in the context of the IMF technical assistance to Albania financed by the Swiss Government.

The paper broke down the lower policy rate bound in two distinct but related concepts: the technical lower bound (TLB) and the effective lower bound (ELB):

- $\quad$ The TLB is the nominal interest rate at which the transmission mechanism (understood mostly through the interest rate channel) breaks down completely. This would happen at an interest level below which a wide-scale shift of financial assets into cash would occur. Such large-scale shift would deprive monetary policy of its leverage on economic and financial agents.

- $\quad$ The ELB is the point at which either (1) the monetary policy, conducted through the conventional policy rate lever, becomes ineffective; or (2) unintended and adverse consequences, coming from policy rate cuts, imply a negative risk-reward profile for policymakers. At that point, policymakers should consider employing additional policy tools, either as a substitute or as a complement to further policy rate cuts.

The ELB may, therefore, coincide with the TLB if lower policy rates would bring minor adverse consequences. However, if adverse consequences are significant at a level higher than the level at which cash hoarding takes place, the minimum level at which the main policy rate can be effectively cut will be equal or higher than the TLB. The ELB concept, therefore, encapsulates the TLB concept. 
The paper is structured as follows. Section I estimates the impact of the lower deposit rate on the demand for banknotes in Albania, including the demand for large denomination banknotes. Section II analyzes the determinants of the ELB. Section III proposes a framework to monitor the unintended consequences of low rates and, thus, the ELB. Section IV concludes.

\section{Determinants Of THE TeChNiCAL LOWER BOUND}

The TLB depends on the sensitivity of the demand for banknotes to the interest rate paid on banks' deposits. The public demand for banknotes is essentially motivated by transactions purposes, such as having cash in advance for the payment of goods and services. It is also motivated, to a lesser extent, to serve as a store of value. Accordingly, the public's demand for banknotes would be determined by variables that influence the amount of transactions in an economy (GDP and prices), portfolio decisions, and innovations in payment methods that reduce the use of banknotes (El Hamiani Khatat forthcoming). On the other hand, the portfolio decisions depend on the interest rate as it represents the opportunity cost of holding zeroyielding banknotes instead of interest rate-bearing assets. The influence of interest rate on the demand for banknotes is the focus of this section.

\section{A. The Demand for Banknotes in Albania}

The public preference for banknotes remains high in Albania, despite a relatively deep financial sector. Currency in circulation as a percentage of GDP and M3 is higher in Albania that in its regional peer (Figure 1). However, broad money to GDP is higher in Albania than in its peer countries. The size of Albania banking sector balance sheet compared to GDP is increased by the remittances accounts of the Albanian diaspora in the local banking sector, which explains the relative financial depth.

Several factors could explain the preference for cash in Albania. First, the public experienced a banking crisis in the late 1990's that affected its perception of banks' soundness. In these circumstances, risk considerations encourage the public to prefer zero-yielding cash to remunerated deposits in banks despite the opportunity cost of holding cash even if the interest rates on bank deposits are high. Second, there is a hysteresis effect as people are used to cash and have already borne the fixed costs related to cash handling. Third, penetration of banking services, though improving, has been low in rural areas and the payment infrastructure was underdeveloped until recently. Finally, a large informal economy, which some estimates place at 40 percent of GDP, also underpins the public preference to keep cash outside the banking system.

The cash-to-M3 or cash-to-GDP ratios have been, until recently, on a secular declining trend. This trend reflects the formalization of the economy, the increasing trust toward Albanian financial institutions, as evidenced in the survey carried in the region by the Austrian central bank (OeNB 2016), and the development of the domestic payment system (Figure 2). However, this trend stopped and even slightly reversed since interest rates on domestic currency (the Albanian lek) deposit reached historically low levels in 2014. 


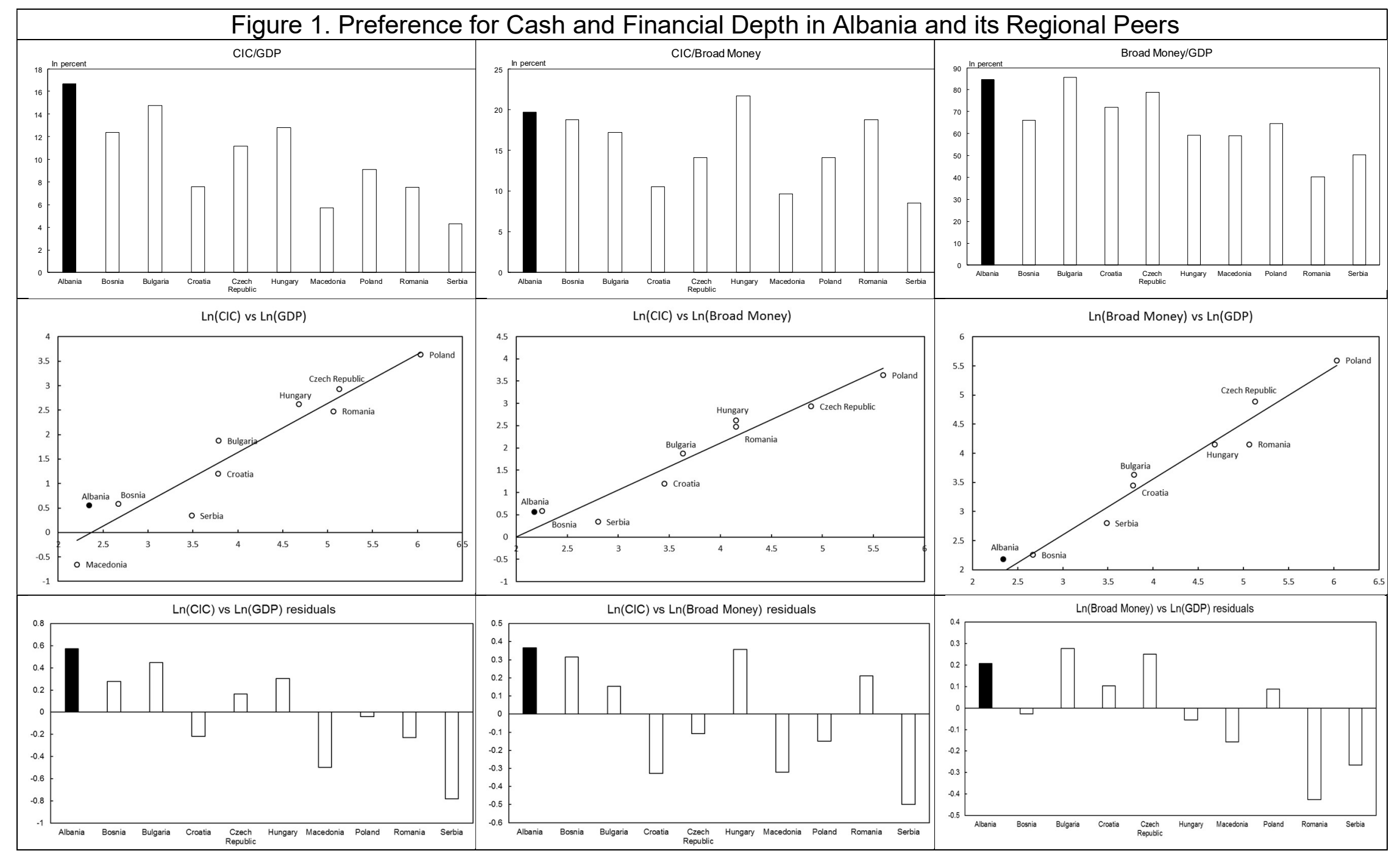

Note 1: CiC: currency in circulation.

Note 2: GDP: gross domestic product.

Sources: IFS, and IMF staff computation 
Figure 2. Evolution of Cash to GDP and Cash to M3 ratio

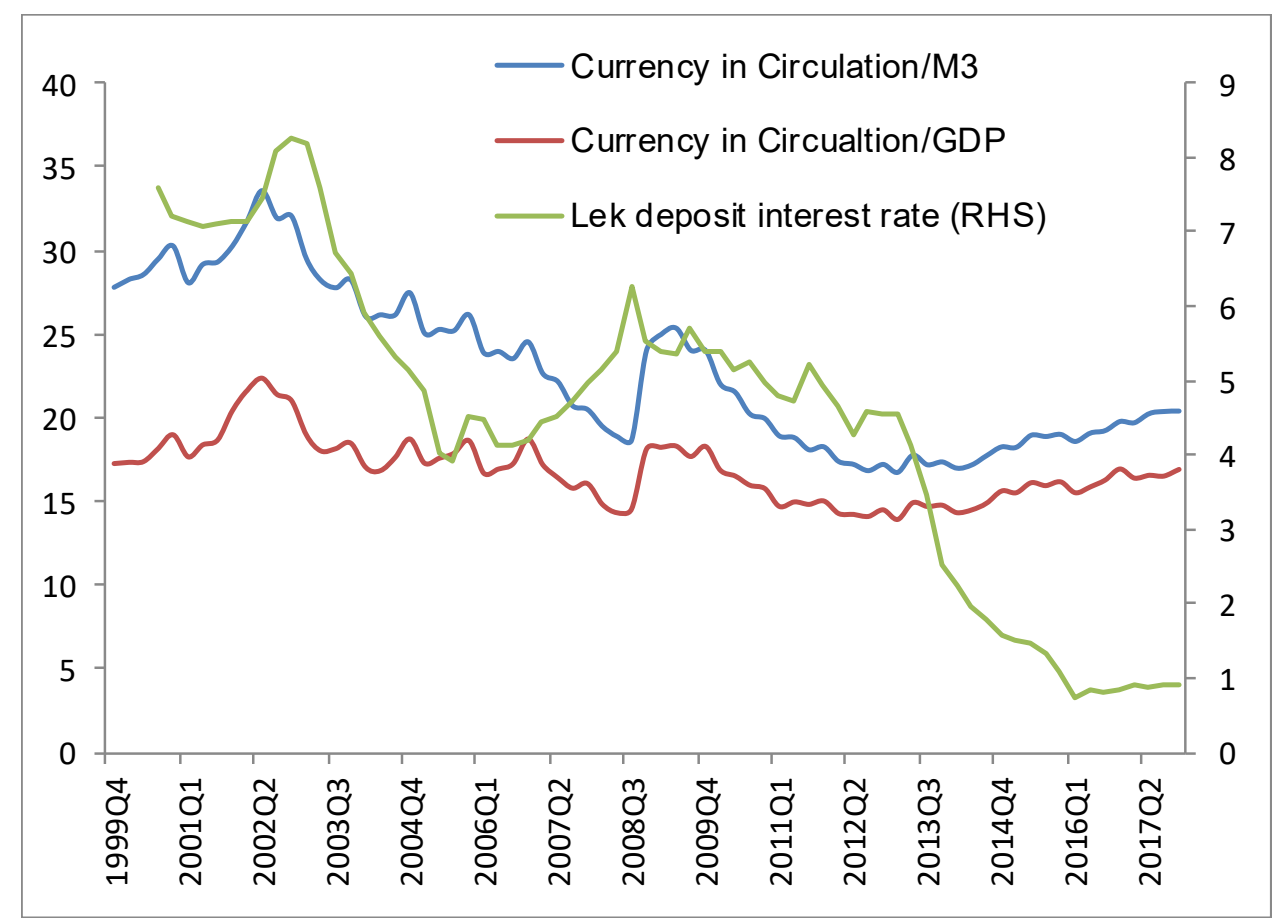

Source: BoA.

We estimated the demand for banknotes for a panel of countries. The estimate assumes a relationship between the public demand for banknotes (currency in circulation as a percentage of GDP) and (1) capital market development; (2) financial depth (local currency deposit as a percentage of GDP); and (3) the local deposit rate. Capital market development, which is added to control for innovations in the payment systems, is proxied by real GDP per capita. Capital market development is expected to reduce the demand for banknotes.

Financial depth is expected to increase the demand for banknotes under the assumption of a constant ratio between currency outside depository corporations and total deposits. The local currency deposit rate is expected to be negatively correlated with the demand for banknotes as the deposit rate represents the opportunity cost of holding banknotes. Foreign currency deposits were added to control for foreign banknotes in circulation, which should reduce the demand of local banknotes for transactional purposes. The estimated equation 1 follows:

Equation 1. $y_{i t}=\alpha_{0}+\alpha_{1} \log (G D P P C)_{i t}+\alpha_{2} L D E P_{i t}+\alpha_{3} F D E P_{i t}+\alpha_{4} L D E P R_{i t}+\gamma_{i}+$ $\gamma_{t}+u_{i t}$

$y_{i t}$ : Local currency in circulation to GDP ratio for country $i$ in year $t$

$\log (G D P P C)_{i t}: \log$ GDP per capita for country $i$ in year $t$

$L D E P_{i t}$ : Local currency deposit to GDP for country $i$ in year $t$

$F D E P_{i t}$ : Foreign currency deposit to GDP for country $i$ in year $t$ 
$L D E P R_{i t}$ : Local currency deposit rate for country $i$ in year $t$

$\gamma_{i}$ : Country-fixed effects

$\gamma_{t}$ : Year-fixed effects

In addition, we estimated the demand for banknote for Albania specifically. The estimation is based on a quarterly vector error correction model that includes a long-term relation and the short-term dynamic (Equation 2). The same variables of the panel regression are included in the error correction model. The error correction model is presented by the following equation:

\section{Equation 2. Vector Auto-Correction Model (VECM) for Albania}

$$
\Delta y_{t}=\alpha\left(\beta \quad y_{t-1}+\mu+\rho t\right)+\sum_{i=1}^{p-1} \Gamma_{i} \Delta y_{t-1}+v+\tau t+u_{t}
$$

where

$y_{t}: 5 \times 1$ vector of variables (i.e., local currency to GDP, log GDP per capita, local currency deposit to GDP, foreign currency deposit to GDP, and local currency deposit rate)

$\alpha: 5 \times r$ rank matrix

$\beta: 5 \times r$ rank matrix

$\mu: r \times 1$ vector of parameters

$\rho: r \times 1$ vector of parameters

$\Gamma_{i}: 5 \times 5$ matrix of parameters

$v: 5 \times 1$ vector of parameters

$\tau: 5 \times 1$ vector of parameters

$\varepsilon_{t}: 5 \times 1$ vector of disturbances

Low deposit rates appear to boost the demand of banknotes in most countries. Table 1 presents the results of the panel estimates. Capital market development has the expected negative impact on the demand of banknotes. Financial depth is positively correlated with the demand of banknotes. Foreign currency deposits reduce the demand of local currency banknotes as expected. The negative correlation between the deposit rate and the demand of banknotes is corroborated by the panel estimates. The Albania fixed effect is positive and significant, reflecting unobserved country-specific effects that increase the preference for banknotes in Albania.

Time series estimates for Albania corroborate the assumption that low rates significantly support the demand of banknotes. Table 1 presents the results of the VECM for Albania. There is a significant long-term relationship between the variables. Deposit rates are significantly and negatively correlated with the demand of banknotes both in the long and 
short term. The negative correlation appears higher in Albania than in the other countries included in the panel regression. Another difference between the time series and the panel estimate is the negative correlation between financial depth and the demand of banknotes in Albania. This negative correlation could reflect the ongoing process of inclusion of part of the population in the banking system.

Table 1. Estimates of the Demand of Banknotes

\begin{tabular}{|c|c|c|c|c|}
\hline \multirow[b]{2}{*}{ Variables } & \multicolumn{2}{|c|}{ Panel of countries } & \multicolumn{2}{|c|}{ Albania VECM } \\
\hline & $\begin{array}{l}\text { Local CIC to } \\
\text { GDP }\end{array}$ & Local CIC to GDP & $\begin{array}{l}\text { Co-integrating } \\
\text { equation }\end{array}$ & $\begin{array}{l}\text { Error correction } \\
\text { equation }\end{array}$ \\
\hline \multirow[t]{2}{*}{ Local currency in circulation to GDP } & & & & $-0.298^{* * *}$ \\
\hline & & & & $(5.06)$ \\
\hline \multirow[t]{2}{*}{ Log GDP per capita } & $-1.484^{* * *}$ & $-1.247^{* \star *}$ & $-1.180^{*}$ & $-3.637^{* * *}$ \\
\hline & $(-5.566)$ & $(-3.387)$ & $(-1.75)$ & $(-3.27)$ \\
\hline \multirow[t]{2}{*}{ Local currency deposit to GDP } & $0.0142^{* * *}$ & $0.0123^{* *}$ & $-0.122^{* * *}$ & $-0.0549^{* * *}$ \\
\hline & $(2.776)$ & $(2.206)$ & $(-4.86)$ & $(-5.21)$ \\
\hline \multirow[t]{2}{*}{ Foreign currency deposit to GDP } & $-0.0402^{* \star *}$ & -0.00614 & $-0.019^{* \star *}$ & -0.163 \\
\hline & $(-3.458)$ & $(-0.453)$ & $(-2.96)$ & $(-1.01)$ \\
\hline \multirow[t]{2}{*}{ Local currency deposit rate } & $-0.0385^{\star}$ & $-0.0422^{* *}$ & $-0.314^{* * *}$ & $-0.389^{* *}$ \\
\hline & $(-1.801)$ & $(-1.978)$ & $(-2.72)$ & $(-2.16)$ \\
\hline \multirow[t]{2}{*}{ Albania } & $4.862^{* * *}$ & -0.696 & & \\
\hline & $(5.648)$ & $(-1.334)$ & & \\
\hline \multirow[t]{2}{*}{ Constant } & $23.97^{\star * *}$ & 0.535 & 2.35 & $-0.434^{* * *}$ \\
\hline & $(14.66)$ & $(1.386)$ & $(-0.17)$. & $(-5.48)$ \\
\hline Observations & 1,503 & 1,349 & \multicolumn{2}{|c|}{57} \\
\hline R-squared & 0.932 & 0.143 & & \\
\hline Time period & $2006-2015$ & $2006-2015$ & \multicolumn{2}{|c|}{2002 Q2 - 2016 Q2 } \\
\hline Number of countries & 154 & 154 & & \\
\hline 1st-difference & No & Yes & \multirow[t]{3}{*}{ No } & Yes \\
\hline Country FE & Yes & Yes & & \\
\hline Year FE & Yes & Yes & & \\
\hline AIC & & & \multicolumn{2}{|c|}{12.64} \\
\hline HQIC & & & \multicolumn{2}{|c|}{13.18} \\
\hline SBIC & & & \multicolumn{2}{|c|}{14.04} \\
\hline
\end{tabular}

Source: IFS, and IMF staff computation

\section{B. The Demand of Large Denomination Banknotes}

An increase in the demand of large-denomination banknotes is often monitored as a sign of interest rates proximity to the lower bound. Large denomination notes are, in fact, typically used as store of value unlike smaller denominations more commonly used for transactional purposes. The share of the two largest denominations (the equivalent of $\$ 60$ and $\$ 25$ ) 
increased from less than 10 percent to more than 30 percent during the last 10 years (Figure 3). The share of smaller banknotes has declined with time while medium-sized banknotes have remained stable as a percentage of the total circulation.

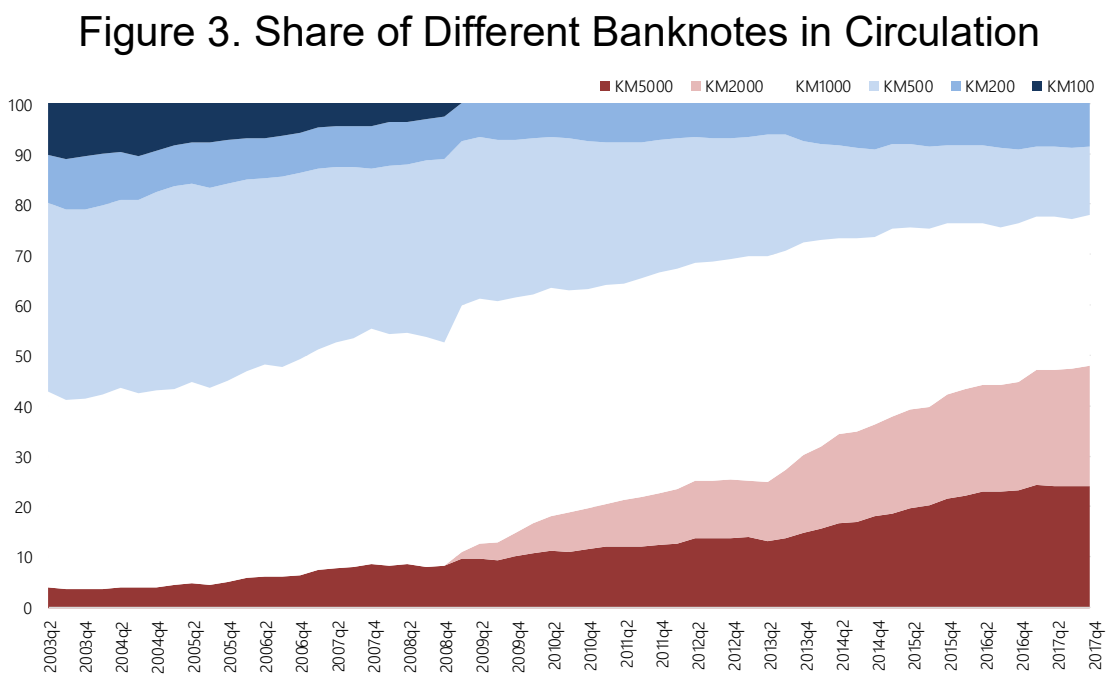

Source: BoA.

The composition of banknotes in circulation depends on several factors. As covered in the central banking literature (see Kohli 1987 and Mougeat 1997), banknotes in circulation are a function of (1) customer real income (GDP per capita), (2) average price level (consumer price index), and (3) the opportunity cost of holding banknotes (deposit interest rate), which is the variable of interest. We added to the estimate the remuneration of foreign currency deposits to control for possible arbitrage between lek large-denomination banknotes and euro deposits. We also added a dummy variable to control for seasonal fluctuations in currency in circulation (Equation 3).

Equation 3. $y_{t}=\alpha_{0}+\alpha_{1} \log (R G D P P C)_{t}+\alpha_{2} \log (C P I)_{t}+\alpha_{3} L D E P R_{t}+\alpha_{4} F D E P R_{t}+$ $\gamma_{t}+u_{t}$

where

$y_{t}$ : Share of a type of banknote over all banknotes in circulation

$\log (R G D P P C)_{t}:$ Log real GDP per capita

$\log (C P I)_{t}: \log \mathrm{CPI}$

$L D E P R_{t}$ : Local currency deposit rate

$F D E P R_{t}$ : Foreign currency deposit rate

$\gamma_{t}$ : Quarter indicators

Lower interest rates support the demand of large denomination banknotes. Table 2 presents the results of an estimate of the determinants of the share of each banknote in circulation. 
The relative increase in large-denomination banknotes was mainly driven by real economic growth and inflation, as expected. However, the demand of large-denomination banknotes is also negatively and significantly correlated with the lek deposit remuneration rates. This negative correlation is an indicator of the sensitivity of potential depositors to the remuneration rate even when interest rates remain positive. Higher remuneration rates increase the opportunity cost of carrying banknotes as a store of value and, therefore, reduce the demand of large denomination notes. Moreover, smaller-denomination banknotes are not significantly correlated with lek deposit rates as expected. In addition, the demand of large denomination banknotes is also negatively and significantly correlated with the euro deposit remuneration. This correlation underscores the importance of the lek-euro interest rate spread. The importance of this spread will be discussed in the next section.

Table 2. Estimates of Banknote Composition

\begin{tabular}{lcccccc}
\hline & $(1)$ & $(2)$ & $(3)$ & $(4)$ & $(5)$ & $(6)$ \\
Variables & Shr5000 & Shr2000 & Shr1000 & Shr500 & Shr200 & Shr100 \\
\hline Log(realGDPpercapita) & $9.947^{* *}$ & 2.168 & $22.60^{*}$ & 10.94 & -3.279 & $-9.781^{*}$ \\
& $(2.134)$ & $(0.238)$ & $(1.888)$ & $(1.283)$ & $(-0.918)$ & $(-1.921)$ \\
Log(CPI) & $24.11^{* * *}$ & $67.24^{* * *}$ & -26.35 & $-88.43^{* * *}$ & -2.978 & $20.93^{* *}$ \\
& $(2.951)$ & $(6.311)$ & $(-1.256)$ & $(-5.913)$ & $(-0.476)$ & $(2.482)$ \\
Lek deposit rate & $-0.518^{* * *}$ & $-0.887^{*}$ & $0.939^{* *}$ & 0.225 & -0.139 & $0.669^{\star * *}$ \\
& $(-3.299)$ & $(-1.825)$ & $(2.329)$ & $(0.782)$ & $(-1.153)$ & $(4.574)$ \\
Euro deposit rate & $-0.938^{* * *}$ & -0.972 & $2.283^{* * *}$ & $1.428^{* * *}$ & -0.284 & $-2.507^{* * *}$ \\
& $(-3.784)$ & $(-1.400)$ & $(3.587)$ & $(3.149)$ & $(-1.496)$ & $(-11.53)$ \\
Second quarter & $-1.524^{*}$ & -0.266 & $-3.908^{*}$ & -2.164 & 0.384 & $2.092^{* *}$ \\
& $(-1.787)$ & $(-0.177)$ & $(-1.784)$ & $(-1.386)$ & $(0.588)$ & $(2.294)$ \\
Third quarter & $-1.282^{*}$ & 0.375 & $-3.149^{*}$ & -1.072 & 0.468 & $2.112^{\star * *}$ \\
& $(-2.003)$ & $(0.407)$ & $(-1.915)$ & $(-0.915)$ & $(0.955)$ & $(2.848)$ \\
Fourth quarter & $-1.346^{*}$ & 0.292 & $-3.343^{*}$ & -1.408 & 0.668 & $1.724^{*}$ \\
& $(-1.804)$ & $(0.250)$ & $(-1.744)$ & $(-1.031)$ & $(1.168)$ & $(2.007)$ \\
Constant & $-137.7^{* * *}$ & $-299.3^{* * *}$ & 49.51 & $371.9^{* \star *}$ & $37.11^{* * *}$ & $-40.13^{* *}$ \\
& $(-7.910)$ & $(-8.983)$ & $(1.107)$ & $(11.67)$ & $(2.783)$ & $(-2.473)$ \\
Time period & & & & & & \\
& $2003 \mathrm{Q} 2-$ & $2009 \mathrm{Q} 1-$ & $2003 \mathrm{Q} 2-$ & $2003 \mathrm{Q} 2-$ & $2003 \mathrm{Q} 2-$ & $2003 \mathrm{Q} 2-$ \\
Observations & $2016 \mathrm{Q} 2$ & $2016 \mathrm{Q} 2$ & $2016 \mathrm{Q} 2$ & $2016 \mathrm{Q} 2$ & $2016 \mathrm{Q} 2$ & $2016 \mathrm{Q} 2$ \\
R-squared & 53 & 30 & 53 & 53 & 53 & 29 \\
Residual stationarity & 0.969 & 0.986 & 0.710 & 0.960 & 0.540 & 0.959 \\
Johansen tests & $5 \%$ level & $10 \%$ level & No & $5 \%$ level & $10 \%$ level & $5 \%$ level \\
\hline
\end{tabular}

Note: Shr: share in total bank notes issued

Source: BoA, IFS, and IMF staff computation

In conclusion, the assessment of the data points out to the existence of a strong and negative correlation between interest rates and demand for cash. The correlation is particularly strong for large denomination banknotes. Low interest rates contributed to slow down the historical process of financial deepening. The TLB has not been reached yet since the increase in banknotes' demands, although significant, does not signal yet the large-scale shift into cash, which may seriously impair the transmission mechanism. The trend, however, calls for cautiousness for two main reasons. First, the relationship between interest rates and cash 
demand is likely to present nonlinearities (that is, the negative correlation could surge below a certain interest rate level). Second, investors may develop alternative strategies if returns remain below the minimum acceptable for longer periods.

\section{Determinants OF THE EFFECTIVE LOWER BOUND}

This section reviews the unintended and adverse consequences that may affect the appeal of cutting policy rates beyond a certain point regardless of large-scale shift into cash. The ELB is determined by the assessment of the likelihood these risks may materialize. It is also determined by the careful analysis of the comparative risk and reward profile of alternative monetary policy tools when the likelihood these risks increases. The range of consequences can be categorized in two groups: (1) those affecting the functioning and the efficiency of the transmission mechanism and (2) those affecting financial stability.

The identification of unintended consequences does not signal per se that the ELB has been reached due to the following reasons:

- The unintended consequences may be mitigated or neutralized through other changes in the monetary policy framework aimed at enhancing the effectiveness of the transmission mechanism at lower interest rates.

- The unintended consequences may develop through time if interest rates remain low for long. Therefore, central banks may still cut rates further and monitor the possible development of unintended consequences.

- Even if unintended consequences are identified, policy makers need to assess the trade-off between unintended consequences of low policy rates and a policy rate higher than necessary to pursue the medium-term price stability objective.

The estimated ELB can change over time because (1) the patterns of the factors from which it depends may vary; (2) the central bank assessment of the pros and cons of downward adjustment of the ELB and of the relative merits of the policy rate cuts vis-à-vis alternative monetary policy actions may be modified; (3) economic agents react and adapt to central bank's actions adjusting the lower bound downward or upward; and (4) the policy actions sequencing influences the assessment of the ELB. In particular, the policy rates may reach a point where the central bank considers relatively more effective to address downside risks to price stability via alternative policy tools (the so-called "non-conventional monetary policy tools," which are not transmitted via the policy rate). However, after having used these nonconventional tools, the central bank may reassess the lower bound and consider further downward adjustments in the policy rates.

\section{A. Impairment in the Transmission Mechanism}

In addition to the risk of cash hoarding (the TLB), the transmission of low interest rates can be impaired by two phenomena analyzed below: (1) rigidities and nonlinearities of the transmission mechanism and (2) the impact of euroization on the credit channel. 


\section{Rigidities and nonlinearities}

Policy rates cuts may not be transmitted to lending rates because of the rigidities of banks' funding cost at low interest rates. Lower policy rates are in general transmitted to the real economy via lower lending rates that should ultimately stimulate credit demand, credit growth, consumption, and investment. They are also transmitted via lower deposit rates that, all else equal, should encourage higher present consumption and lower savings. However, banks may not be willing to lower deposit rates enough at low rates because of the risk of deposit outflows. Further, if funding costs are rigid at the zero bound, banks may not react to lower policy rates with lower lending rates as they attempt to maintain their interest rate margin unchanged and preserve profitability (Bech and Malkhozov 2016).

The extent in which low policy rates are effectively transmitted depends on banks' funding structure. Lower policy rates are transmitted effectively to money market rates and, from there, to the whole term structure of market rates. This is evidenced by the transmission of negative policy rates in Denmark, the euro area, Sweden, and Switzerland (see Bech and Malkhozov 2016, Jobst and Lin 2016, and Viñals, Gray, and Eckhold 2016). However, international evidence shows that negative rates were not transmitted to retail deposit rates. Therefore, the overall transmission of negative rates to the banks' weighted average funding costs is higher when wholesale funding accounts for a relatively higher share in the overall banking system's funding. It is also higher when the elasticity of the clients' deposit supply to the interest rate levels is low. This is not the case in less developed financial markets, such as Albania, where we have seen that the elasticity is high.

The regulation on deposit remuneration unwittingly reinforces the nominal rigidity of interest rates at low policy rates levels. Due to disintermediation concerns, authorities in most small, open, and euroized economies explicitly or implicitly prevented banks to remunerate customer funding at negative rates. This took place even for large corporate deposits denominated in euro, despite the negative rates prevailing in the euro area money markets. Similarly, most central banks in small, open, and euroized economies do not remunerate the reserve requirement on euro deposits, thereby providing banks with a higher remuneration than the market yield on comparable high-quality and short-term euro assets. Banks in small, open, and euroized economies, enjoying a supply of funding in foreign currency exceeding domestic investment opportunities, could have transmitted the negative rates to clients' deposit denominated in euro, at least to large corporate deposits and to clients deposits exceeding certain quantitative thresholds. Such transmission would have increased the spread between domestic currency deposits and euro deposits, providing more room for futher policy rate cuts.

In Albania, the monetary policy pass-through has not declined so far with the decrease in the policy rate level toward 1 percent. Changes in the policy rate completely passed through to the interest rates of new deposits and new credits (Figure 4), which hints at some more room to cut the policy rate toward the technical lower band. Figure 5 shows that the rate cut also transmitted to the risk-free yield curve with a tendency for the curve to flatten at low rates. 
Figure 4. Deposit Rate and Policy Rate (percent)

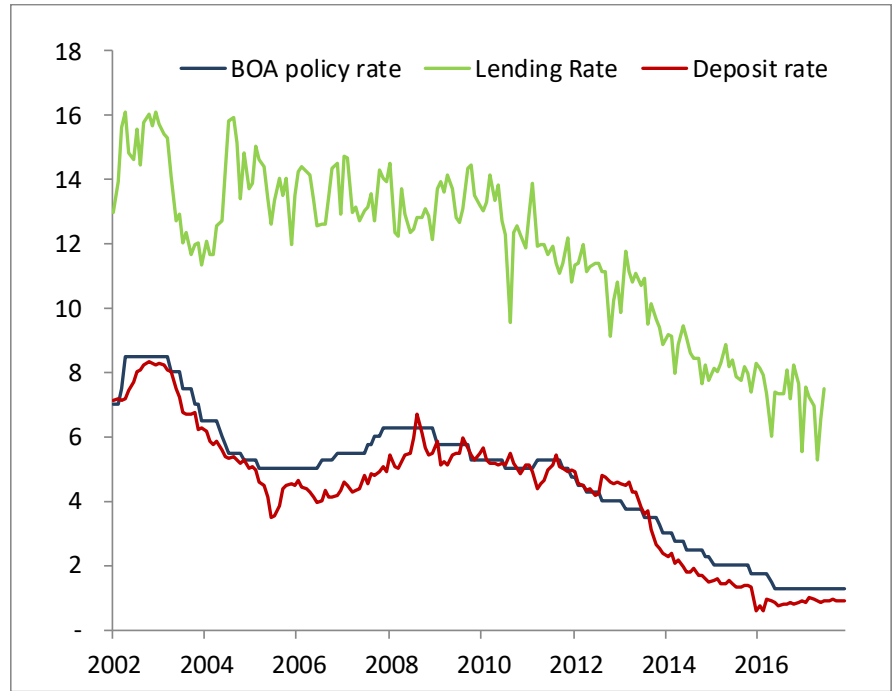

Sources BoA and authors' calculations.

Figure 5. Risk-Free Yield Curve (Percent; average period)

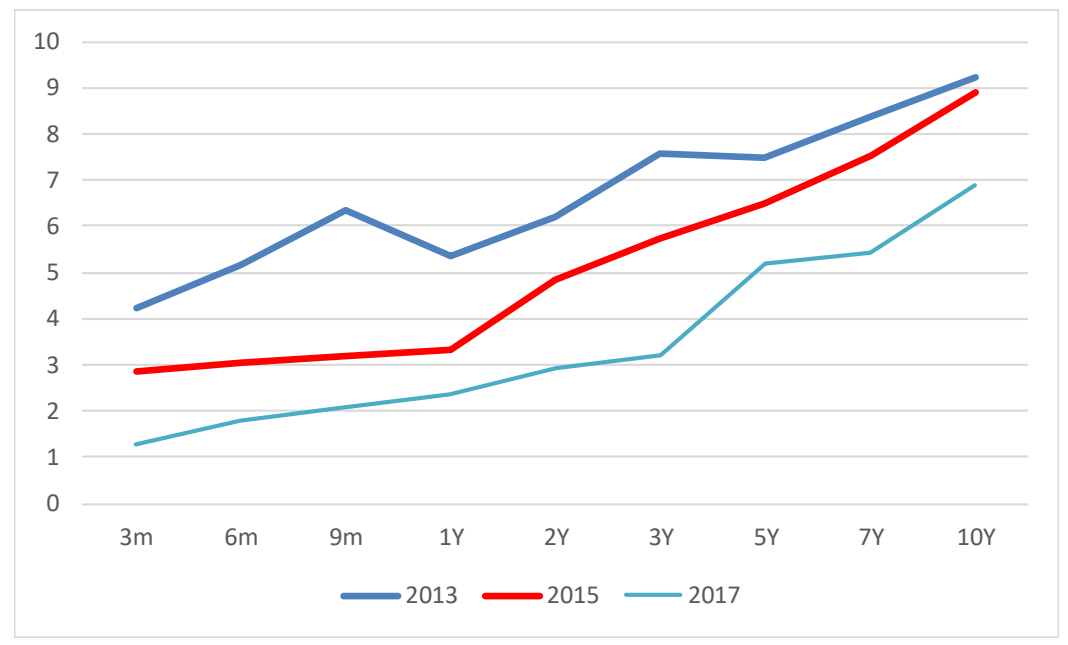

Sources: BoA and authors' calculation.

\section{Euroization and the exchange rate channel}

The depreciation of the exchange rate is an important transmission mechanism for low interest rate policies, particularly in small and open economies. Central banks may ease appreciation pressures on the exchange rate or encourage a depreciation to boost export, domestic demand, and local prices. This effect takes place by reducing the financial attractiveness of domestic assets versus foreign assets via very low or negative interest rates. The exchange rate effect has been the main driver of transmission of the negative policy rates in most economies that adopted them. Indeed, they tried to stem exchange rate appreciation pressures by penalizing capital inflows (see Bech and Malkhozov 2016). 
However, the exchange rate and credit transmission channels of monetary policy tend to conflict with each other in a euroized economy. In significantly euroized economies, such as Albania, there is a risk that below a certain interest rate differential between domestic and foreign currency-denominated assets, the exchange rate will significantly depreciate, leading to the two following negative effects on monetary policy transmission:

First, exchange rate depreciation would increase the debt servicing costs of a significant proportion of banks' loans denominated in foreign currency. Higher debt servicing costs may result in more non-performing loans (NPLs), higher provisions and lower banks' profitability. In turn, banks would try to compensate for lost revenues and the higher riskiness, by increasing the lending rates. Such increase would offset the intended credit easing objective (Figure 6). Econometric analysis conducted by BoA corroborates this assumption. Credit risk premia on new loans are strongly correlated to past exchange rate developments.

Second, the depreciation would encourage further financial euroization, thereby reducing monetary policy scope. Downward nominal deposit interest rate rigidity at the zero bound accentuates the problem. A central bank in a euroized economy may consider it undesirable to lower policy rates beyond the point at which the nominal yields on domestic assets fall to a level no longer attractive compared with the yields on foreign currency assets in the domestic financial sector. Such yield on foreign currency assets is unlikely to fall below zero in the local banking system regardless of the foreign policy rates. This lifts the ELB when foreign policy rates are negative.

The central bank may need to maintain, therefore, a minimum interest rate differential in relation to foreign currency-denominated substitute assets to prevent currency reallocation. Such a level should account for nominal rigidities that prevent the remuneration of foreign currency deposits from dropping below zero in the current negative euro area policy rate environment. Such a level also reflects expectations of exchange rate depreciation, which are typically entrenched in euroized economies, and the possibilities of domestic currency portfolio reallocation (e.g., toward longer-dated and higher yielding assets) and other policy actions - such as higher reserve requirements, lower reserve requirement remuneration, stricter HQLA requirements - that may reduce the attractiveness of foreign currency deposits. The availability of such alternative dometsic currency investment opportunities is limited in Albania in light of the limited development and sophistication of the financial system. 
Figure 6. Monetary Policy Transmission in Euroized Economies

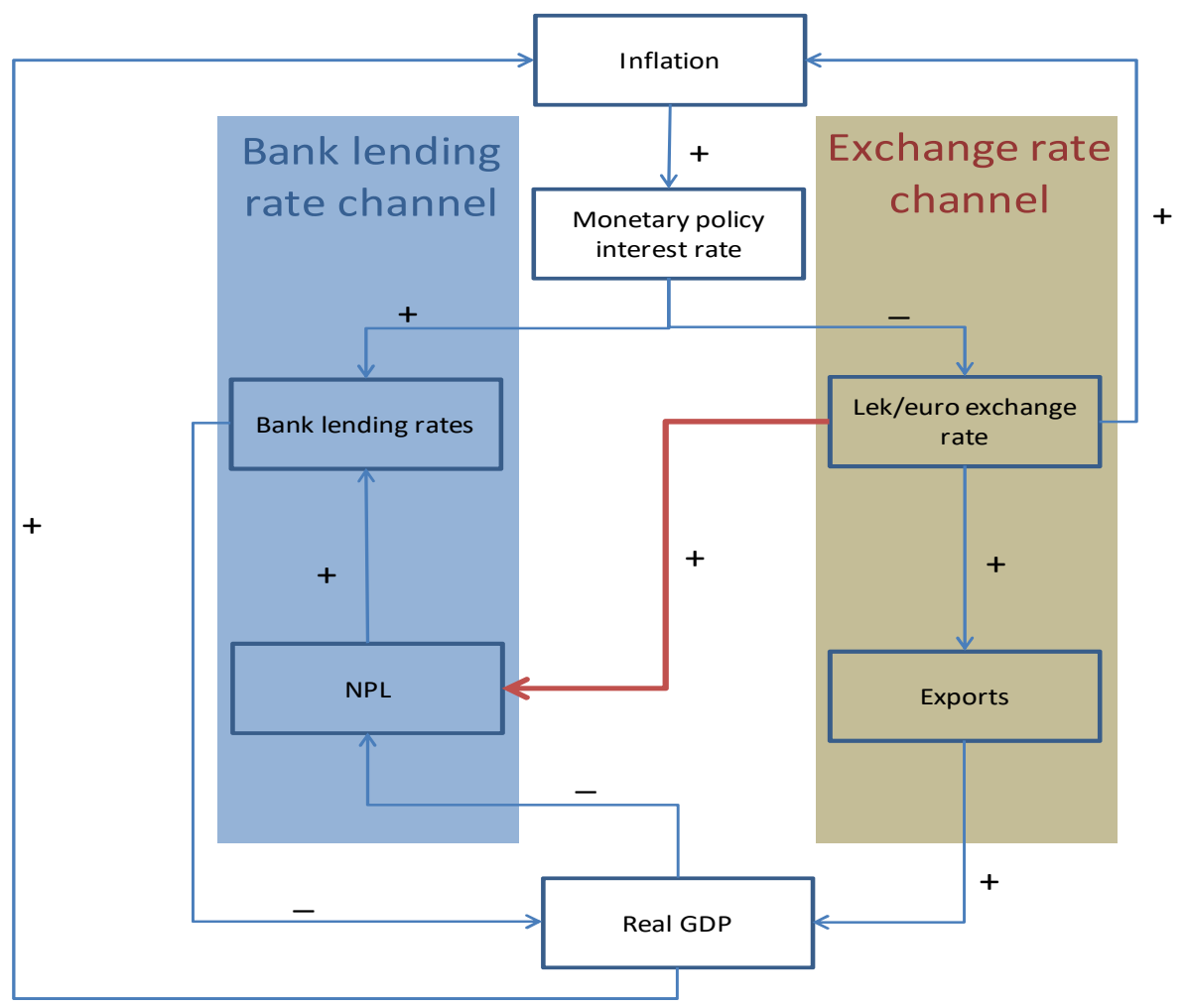

Source: authors

\section{B. Financial Stability}

Low policy rate, or a prolonged period of low interest rates, can have adverse consequences on financial stability. Financial crises should be prevented as they are costly and may engender significant output losses. We identify four channels through which a low policy rate could negatively impact financial stability in Albania: (1) euroization in the presence of large unhedged exposures to exchange rate risk, (2) banks' profitability, (3) banks' funding structure, and (4) the risk of asset bubbles.

\section{Euroization}

In a euroized economy, such as Albania, financial stability can be highly sensitive to exchange rate developments. The presence of large unhedged positions in the real sector, exposes the financial sector to indirect exchange rate risks. The lek exchange rate depreciation in the aftermath of the crisis increased NPLs on foreign currency-denominated loans. Allowing for the lags and nonlinearities, this depreciation was one of the major driver in the subsequent increase in risk premia as evidenced by the higher incidence of default in foreign currency-loans in relation to lek loans (Figure 7). Stress test analysis at the BoA indicates that a 10 percent depreciation adds 3.1 percentage points to NPL ratios for foreign currency loans in the first year of the exercise and 2.1 percentage points in two years. 
Figure 7. Non-Performing Loans in Euro and Lek

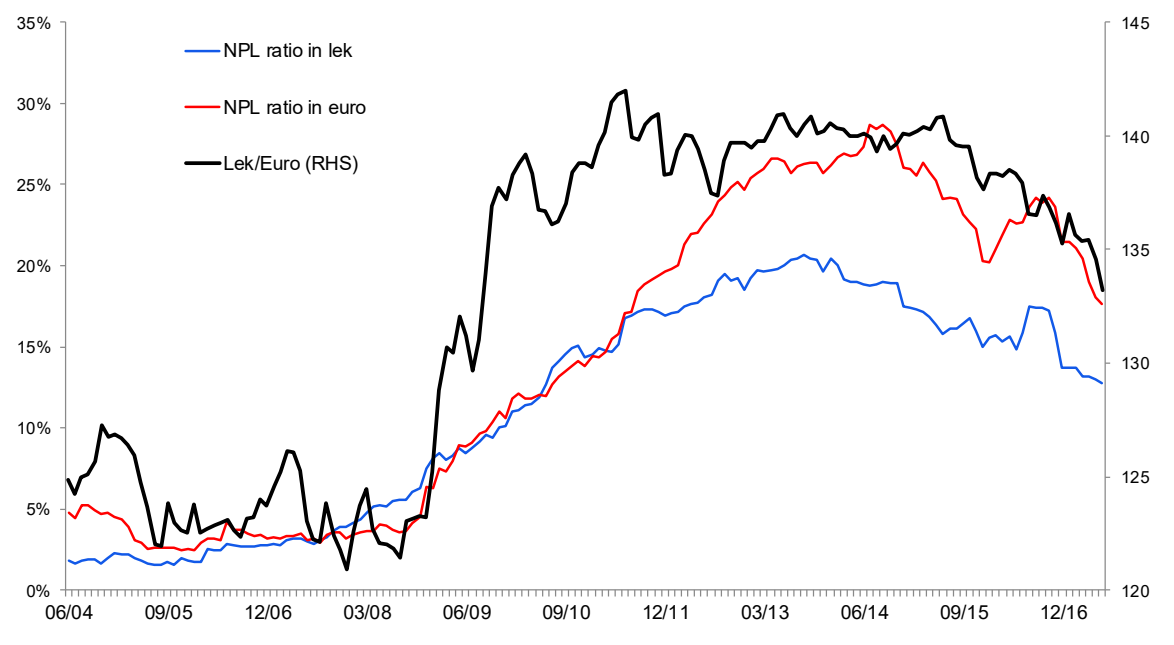

Source: BoA.

Furthermore, low lek interest rates encouraged deposit euroization. Despite a stable exchange rate, low inflation, and improved risk perception - as reflected in a decline in the sovereign spread in line with peer countries of the region - the share of euro deposit increased from 40 percent to 50 percent of total deposits from 2006 to 2016. The supply of euro deposits is, in part, driven by the optimal portfolio choice of risk-adverse investors interested in the riskadjusted return of their portfolios and in euro deposits as a hedge against adverse foreign exchange shocks. Low domestic interest rates - by reducing the relative attractiveness of domestic deposits compared to foreign currency deposits - increase euroization and accentuate long-term financial vulnerabilities.

Hysteresis effects from past periods of instability mean that foreign currency deposits are considered a better safeguard against adverse economic shocks. Domestic deposits should therefore provide a yield premium over foreign currency deposits to make depositors indifferent between the two. An increase of 1 percentage point in the spread between BoA and ECB monetary policy rates reduces the share of foreign currency deposits between 0.8 and 0.9 percentage points during the 2007-16 period according to IMF estimates (Della Valle and others, forthcoming).

\section{Banks' profitability}

Borio and others (2015) show a positive relationship between the level of short-term rates and bank profitability as well as between the slope of the yield curve and bank profitability. The negative impact of low interest rates on net interest income exceeds the positive impact on net profits of lower loan loss provisions - provisions that decline as the debt service to income decline due to lower interest rates-and of higher non-interest income. The effect is stronger when the interest rate level is lower and the slope is less steep. 
This suggests that unusually low interest rates and an unusually flat term structure-which are often associated with forward guidance on extremely low interest rates-erode banks' profitability. The impact of low interest rates on banks' profitability has also been widely discussed by the ECB (Praet 2016). Praet argues that the relationship between interest rates and profitability needs to be assessed on a case-by-case basis. The trade-off between the effects on interest rate margins and on loan loss provision may be different in different contexts.

In a bank-intermediated financial system, monetary authorities have an inherent interest in the soundness of the banking system. Such a sound system influences the transmission mechanism and contributes to strong macroeconomic performances in the long-term. A protracted period of low or even negative profits in banks would have adverse consequences on their capital adequacy ratios. This would impact financial stability, either directly, through a higher default probability, or indirectly, through a deteriorated public perception. This, in turn, would impair banks' funding sources and the costs thereof, as well as the bank's risktaking capability and willingness.

Regardless of flatter yield curve, the profitability of the Albanian banking sector has not been affected. The net interest margin declined to 3.9 percent in 2017 from 4.2 percent at the end of 2016. But it remains close to the long-term average of 4.1 percent, as depicted in Figure 8 . While the interest rates that banks earn on loans and securities have declined, borrowing costs of deposits have also fallen. The decline in funding costs has also been supported by a change in the funding composition toward cheaper source of funding (see below). Net interest income constitutes around 81 percent of the banking sector income as fees contribution has increased only slightly.

Figure 8. Albanian Banking System Net Interest Margin (in percent)

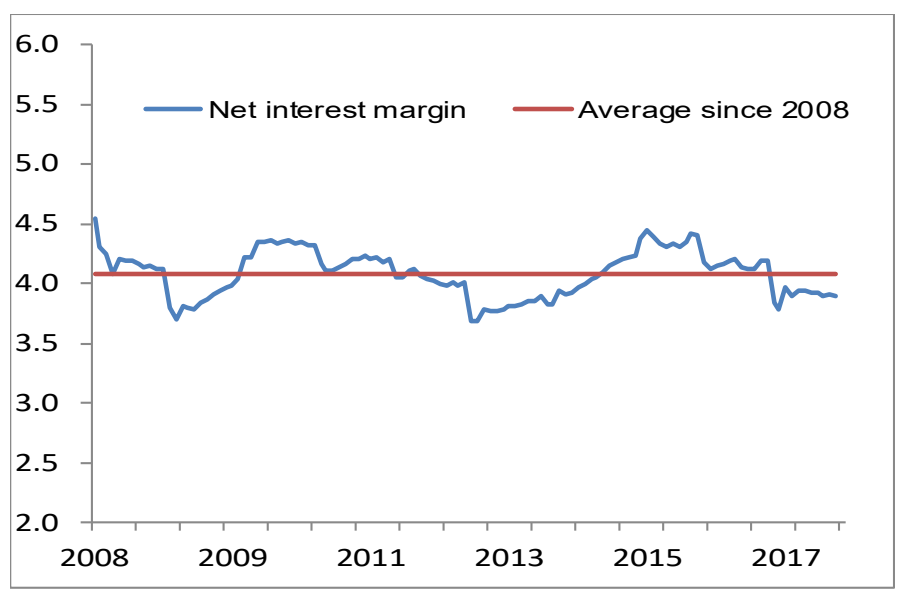

Source: BoA.

\section{Effects of low policy rates on the funding structure}

Another side effect of the low interest environment is a "thinning of the middle" in the maturity structure of banks' funding. As interest rates in traditional savings instruments 
(bank deposits with a maturity between 1 and 12 months) decrease, savers have moved either into current accounts and demand deposits, in search of liquidity, or into longer dated deposits, in search of yields. This shift is depicted in Figure 9, Panel 1. This movement has not, however, induced (1) a shift into more marketable or liquid instruments on the asset side of the banking system, such as government papers (see Figure 9, Panel 2); (2) a shift into shorter-term government paper (see Figure 9, Panel 3), or (3) a shift into credit of lower duration (see Figure 9, Panel 4).

Figure 9. The Impact of Low Interest Rates on the Asset and Liabilities Structure of the Banking System
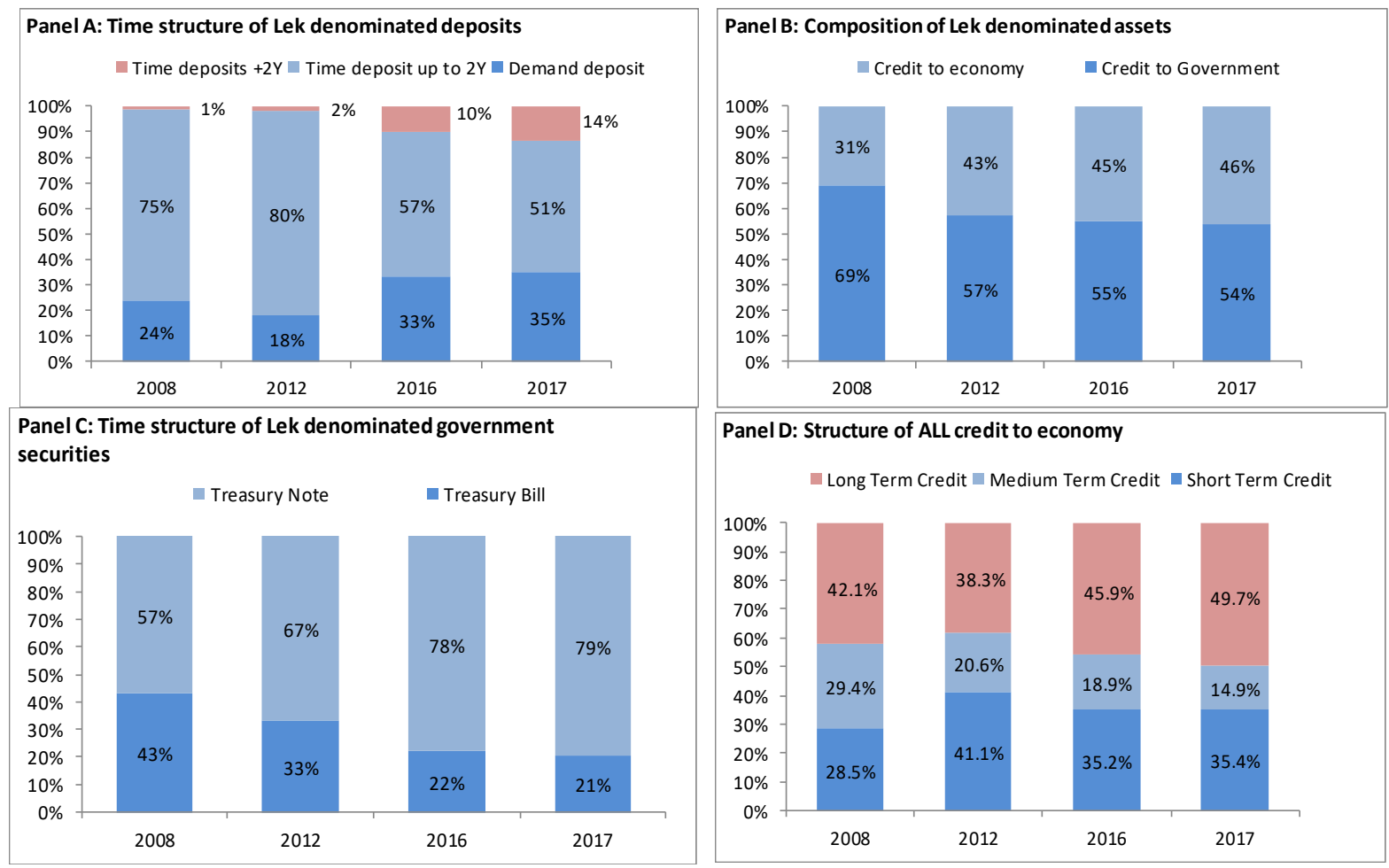

Source: BoA.

\section{Asset bubbles and misallocation of capital}

Protracted low interest rates may stoke asset bubbles and the risk of capital misallocation. Low interest rates encourage investors and banks to "search for yield" by taking additional risks. This is an objective of the low-rate policy to encourage changes in banks' credit policy when risk aversion is considered excessive after protracted periods of economic stagnation and contraction. However, the search for yield and a protracted period of low policy rates can push the market value of assets beyond their fundamentals (creating financial and real asset bubbles) or they can drive an excessive increase in balance sheet leverage. These risks can be mitigated by appropriately targeted micro- and macroprudential policies. However, identifying the materialization of these risks in time to deploy proactive prudential policy responses is not always easy. 
These risks appear low in Albania. Credit growth was moderate during the past five years due to stricter lending standards. Property prices remain sluggish due to a large stock of unsold properties and unfinished projects. Therefore, moderate higher risk taking and a limited boost to the property market can underpin the recovery in economic activity.

\section{Proposal for a Systematic Monitoring Framework}

Unintended consequences as described in the previous section do not materialize abruptly, but there are early warnings that a trend is developing. When there are growing evidences that the unintended consequences are materializing and are reaching a point in which the destabilizing consequences outweigh the benefits of lower rates, it is a signal that the ELB has been reached. When the ELB is approaching, policy rate decisions should assess and anticipate the effects that lower rates may have and the extent in which those effects can be accepted.

This section addresses some of the economic variables to be systematically monitored based on a framework effectively deployed in Albania in 2016. The proposed monitoring system considers six dimensions. They include (1) financial euroization, (2) exchange rate developments and trends, (3) banks' profitability, (4) financial intermediation and disintermediation, (5) average maturity of banks' deposits, and (6) saving rates. The variables suggested are those most significant for small, open, and euroized economies and are included in the BoA monitoring framework. The tool - displayed in Figure 10 - represents a way to operationalize the monitoring of the described dimensions. The "barometer" is used as a device to signal when the transmission of lower interest rates is weakening and/or is producing undesired effects with regards to the relevant financial stability dimensions.

In the barometer, the performance of the indicator is compared against a benchmark measured as the average level and/or standard deviation of the indicator over the past two years. We observe deviations of the current value from the mean to obtain a warning signal. The values of each indicator are normalized on a scale of 0 to 1 where these numbers correspond to the lowest and highest values of the indicator over the past two years. The mean of the series indicates the midpoint of this interval. Hence, current values approaching the upper limit (1) signal a worsening of the performance of that indicator. The opposite holds if current values are approaching the lower limit (0). To provide a simple visual interpretation, values falling in the red area represent a warning signal while those in the green area represent safe conditions. Box 1 provides a description of the variables utilized in Figure 10. 


\section{Box 1. The Variables of the Barometer}

1. The volume of interbank lending as a ratio to the reserve requirement.

- Further lowering of policy rate and the narrowing of the corridor might lower incentives for interbank trading. Considering frictions in the market, it is important to monitor the volume of interbank transactions in relation to reserve requirement needs, so that monetary policy does not endanger activity in this market.

- The data are daily, averaged for the last month and compared to the average of the last two years.

2. The $\mathrm{CiC}$ as a percent of total financial assets in lek. The latter includes deposits in lek as well as government securities in lek held by households.

- Currently, this ratio stands above its average of the last two years. As the interest rate approaches the lower bound, the tendency to keep cash increases considering the opportunity cost. Although it is very difficult to measure the cost of keeping cash, which would ideally be the lower bound of interest rates, monitoring the increase of cash outside banks should give a signal for being close to that bound.

3. The volatility of $\mathrm{CiC} /$ total financial assets in lek measured as the standard deviation of monthly changes.

- This measure captures the speed of a growing preference for keeping cash. As this preference increases, it should give some signal that monetary policy is having adverse effects.

4. The spread of currency deposit interest rate between lek and euro (monthly, time deposit interest rates).

- The spread between time deposit interest rate in euro and that in lek incentivizes the holding of one currency or the other. As the spread minimizes, the incentive to hold hard currency increases, spurring implications for the exchange rate, which in turn endangers financial stability given the considerable share of unhedged loans in euro. Currently, this spread is at the minimum of its historical values of last two years, but with no visible effect on the exchange rate.

5. The euro/lek exchange rate (monthly).

- The level of exchange rate is compared to an average of last two years, in relation to the considerations mentioned above.

6. The volatility of euro/lek exchange rate measured as standard deviation of monthly changes.

- The measure captures the magnitude of depreciation of the euro/lek exchange rate compared to its historical development.

7. Liquid deposit in lek in percent to total deposit in lek for households (monthly).

- Comparable to the meaning of indicator \#2, this indicator gives a signal for savers switching to liquid assets as time deposits start to yield low returns. Currently, this ratio is at the maximum of its last two years.

8. The volatility of the ratio of liquid deposits to total deposits in lek of households measured as a standard deviation of monthly changes.

- This measure captures the magnitude of change of the ratio relative to its average of last year. As the ratio increases, the households' preference to shift to liquid assets is growing faster.

9. Banking system return on equity (monthly).

- This indicator suggests the impact of low interest rates on banks' profitability. As the interest rates for deposit is reaching a low bound (zero), the transmission of monetary policy is expected to affect only the lending rates reducing the interest rate margin, which accounts for a considerable part of income. The measure should exclude eventual one-off changes in provisioning rules.

10. Banking system net interest income-to-risk-weighted-assets ratio (monthly).

- This is a more straightforward indicator that captures the return on banks' policies to invest and to take risk. It also includes investments in securities, but the bulk of risk-weighted assets is composed of lending. The lower the return, the less willing are banks to take risk. Currently this indicator is close to its minimum of the last two years. The data are monthly and include lek and foreign currency assets.

11. Euro deposits as a percent of total financial assets. The latter includes all deposits, as well as government securities held by households (monthly).

1. This indicator compares to indicators \#4 and \#5, and tries to capture the tendency for increasing euroized assets as the return of lek assets diminishes. Increasing euroization is an adverse impact of further easing of monetary policy. Currently, this ratio is slightly below its maximum level over the last two years.

12. Interest rate spread between lending rate in lek and policy rate (monthly).

While this is a very volatile indicator, the correlation between lending rate and policy rate appears to have strengthened in the last two years. Hence the lending rate will follow the movements in policy rate, albeit with some lags. Once this correlation weakens, it warns of fading transmission of policy rates through the lending channel. In tandem, we look at the credit conditions (not included in the barometer). Currently, the spread of lending rate and policy rate is at its minimum over the last two years, while credit conditions are easing gradually.

Source: authors 
The barometer is an effective tool to monitor the different relevant indicators of the effective lower bound. It signals the extent in which undesirable effects are materializing and the relative strength of these effects. It facilitates policy decision, but it does not replace policy judgment on issues such as the trade-off between the costs and the benefits of lower policy rates relative to alternative policies. The indicators to use in the barometer, their relative importance, their number, and the scale to use for each indicator can obviously be adjusted.

The ELB barometer was widely used as a monitoring tool in Albania throughout 2016 and again in 2017. Given the uncertainty over the possibility of a further downward drift of inflation expectations, the need for additional monetary stimulus could not be ruled out. The ELB barometer has continuously been a key instrument used to assess the room for further policy rate cuts and to inform the BoA of the impact of the low interest rate environment on the key identified risk dimensions.

A reading of the barometer as of mid-2017 is depicted in Figure 10. The low policy rate environment was assessed to cause some stress in the identified risk dimensions. The stress was not spread equally across all dimensions, though. Of the 12 identified risk variables, nine are above historical values. Of those nine, four are at or close to historical records. However, a careful reading suggests a nuanced picture.

- While the interest rate differential was at historical lows, it was not inducing any abnormal exchange rate depreciation or exchange rate volatility.

- Furthermore, while a certain trend towards higher euroization levels can be detected, financial disintermediation does not appear to be much of a concern, as evidenced by the cash-to-lek financial assets ratio.

- An external analysis indicates the deterioration in the return on equity is largely due to a spike in provisioning, though risk-adjusted returns in the banking system are close to historical lows.

- Last, despite a trend towards lower maturities in the liabilities side of the banking system balance sheet, the transmission mechanism appears to be not impaired, as evidenced by the reading on spread between loan and policy rates and by the interbank market activity. 
Figure 10. The Effective Lower Bound Barometer in Albania

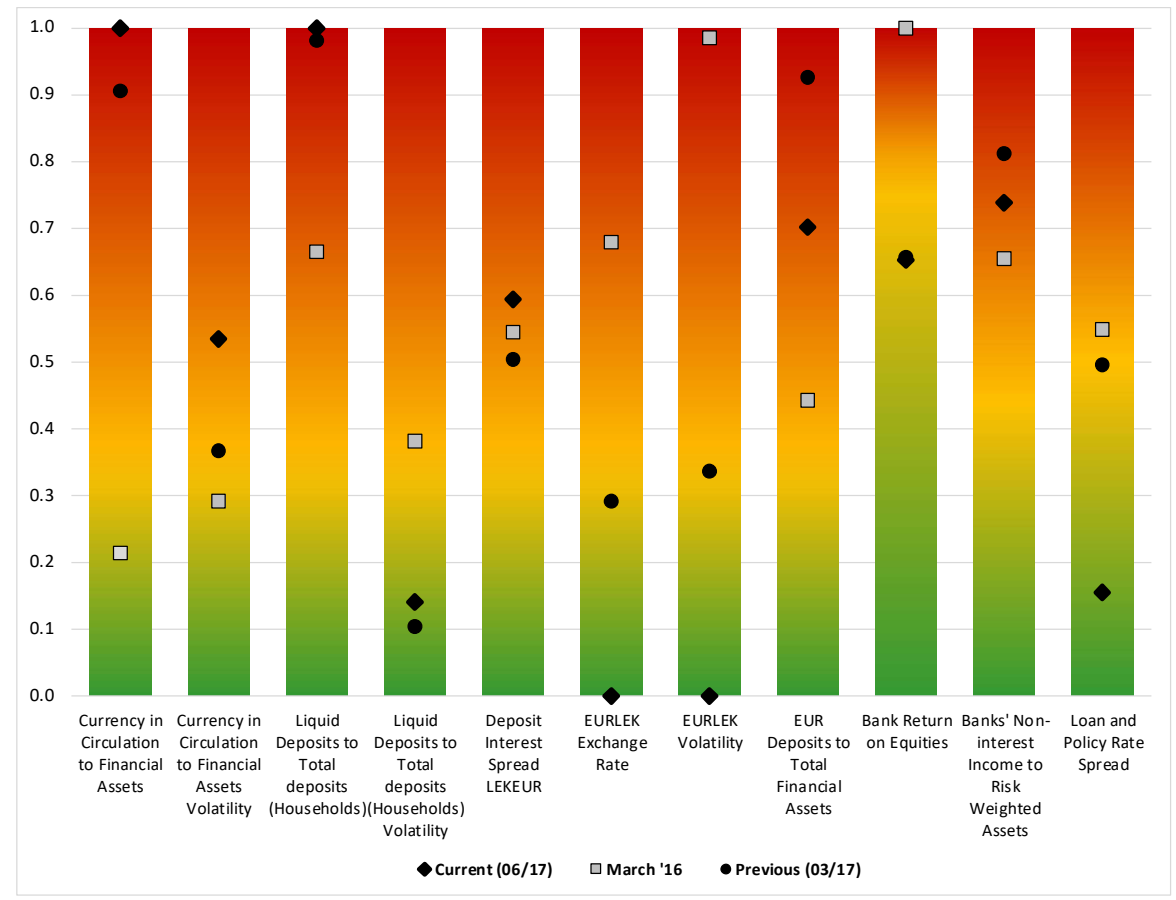

Source: Authors' computation.

\section{Conclusion}

This paper assesses that small, open, and euroized economies have limited scope for policy rate cuts at low interest rate levels. The high preference for cash lifts the TLB in those economies. Therefore, the effectiveness of monetary policy transmission is impaired at higher interest rate levels than in advanced economies due to lower cash opportunity costs. In addition, euroization exacerbates the risk of low interest rates for financial stability, lifting the ELB higher than in advanced economies. As a result, open, small, and euroized economies might have to sustain tighter monetary conditions than necessary in the face of monetary policy spillover from larger and more advances economies, such as the euro area. Alternatively, they may to implement non-conventional monetary policy measures earlier, at a higher policy rate level.

This paper proposes an operational monitoring system to assess the consequences of low policy rates on several variables, thereby contributing to the policy assessment of the ELB. While the technical lower bound may be quantifiable, the ELB cannot be quantified because it includes too many dimensions and policies trade-off. Their monitoring can be facilitated by the "barometer" presented in this paper with the aim of supporting the decision-making process.

In the medium-term, policy actions are needed to attenuate the ELB constraints and, thus, enhance monetary policy potential in small, open, and euroized economies. Reducing the public's preference for cash and for saving in euro is a medium to long-term endeavor that 
would require the development of a credible track record of low and stable inflation as well as financial sector stability.

However, in the short-term, measures to enhance the pass-through of negative euro area interest rates to the domestic financial sector would contribute to attenuate the lower bound constraint deriving from the interest rate differential to be preserved. This chiefly includes: (i) aligning the remuneration rate of foreign currency-denominated reserve requirements to the same rate applied by the ECB on its deposit facility (i.e. -40 basis point); and (ii) allowing banks, according to their own business decisions and assessment, to charge negative interest rates on euro-denominated deposits.

With the Albanian inflation rate underpinned by a narrowing output gap, steady economic growth rates, and lower disinflationary forces from the euro area, the ELB has become somewhat less topical. These factors, although slowly and with a considerable lag, should contribute to return of inflation to target. However, the analysis conducted can be useful along three dimensions. First, the approach adopted and the instrument deployed could be used by other countries facing similar policy challenges. Second, the BoA has now in place a more robust and comprehensive monitoring framework of various intended and unintended consequences of monetary policy decisions. Third, the assessment of the ELB may become topical again at the time of any future easing cycle or if further downside risks to price stability materialize, especially if equilibrium real interest rates remain low in the future. 


\section{Appendix I. Data Sources}

\begin{tabular}{|c|c|c|}
\hline Name & Description & Source \\
\hline Foreign currency deposit & $\begin{array}{l}\text { Deposit denominated in foreign } \\
\text { currency }\end{array}$ & $\begin{array}{l}\text { CEIC, Monetary and Financial } \\
\text { Statistics }\end{array}$ \\
\hline Local currency deposit & $\begin{array}{l}\text { Deposit denominated in local } \\
\text { currency }\end{array}$ & $\begin{array}{l}\text { CEIC, Monetary and Financial } \\
\text { Statistics }\end{array}$ \\
\hline Total deposit & All deposits & CEIC \\
\hline Broad money (M3) & Broad money defined as M3 & CEIC, Bank of Albania \\
\hline $\begin{array}{l}\text { Local currency in } \\
\text { circulation. }\end{array}$ & Local currency in circulation & $\begin{array}{l}\text { Monetary and Financial Statistics, } \\
\text { Bank of Albania }\end{array}$ \\
\hline $\begin{array}{l}\text { Foreign currency in } \\
\text { circulation }\end{array}$ & $\begin{array}{l}\text { Estimated foreign currency in } \\
\text { circulation }\end{array}$ & IMF staff estimates \\
\hline GDP & $\begin{array}{l}\text { Gross domestic product in nominal } \\
\text { terms }\end{array}$ & $\begin{array}{l}\text { World Economic Outlook, Bank of } \\
\text { Albania }\end{array}$ \\
\hline GDP per capita & $\begin{array}{l}\text { Gross domestic product per capita in } \\
\text { nominal terms }\end{array}$ & World Economic Outlook \\
\hline $\begin{array}{l}\text { Local currency deposit } \\
\text { rate }\end{array}$ & $\begin{array}{l}\text { Interest rate on local currency } \\
\text { deposits }\end{array}$ & $\begin{array}{l}\text { World Economic Outlook, Bank of } \\
\text { Albania }\end{array}$ \\
\hline $\begin{array}{l}\text { Foreign currency deposit } \\
\text { rate }\end{array}$ & $\begin{array}{l}\text { Interest rate on foreign currency } \\
\text { deposits }\end{array}$ & Bank of Albania \\
\hline Exchange rates & $\begin{array}{l}\text { Exchange rates of national currency } \\
\text { vis-à-vis euro for Albania, Bosnia, } \\
\text { Bulgaria, Croatia, Czech Republic, } \\
\text { Hungary, Poland, Romania, and } \\
\text { Serbia }\end{array}$ & CEIC \\
\hline Bank notes value & $\begin{array}{l}\text { Value of different banknotes in } \\
\text { circulation in Albania }\end{array}$ & Bank of Albania \\
\hline Real GDP per capita & $\begin{array}{l}\text { Gross domestic product per capita in } \\
\text { real terms }\end{array}$ & Bank of Albania \\
\hline $\mathrm{CPI}$ & Consumer price index & Bank of Albania \\
\hline Policy rate & Central bank policy rate & Bank of Albania \\
\hline NPL & $\begin{array}{l}\text { Nonperforming loans as share of } \\
\text { total loans in lek and euro }\end{array}$ & Bank of Albania \\
\hline $\begin{array}{l}\text { Ratio foreign currency } \\
\text { deposits to total } \\
\text { deposits: }\end{array}$ & $\begin{array}{l}\text { Ratio of foreign currency deposits at } \\
2005 \text { exchange rate over total } \\
\text { deposits; includes households and } \\
\text { business }\end{array}$ & $\begin{array}{l}\text { Bank of Albania and IMF staff } \\
\text { estimates }\end{array}$ \\
\hline Spread policy rates & $\begin{array}{l}\text { Albania repo operation 1-week target } \\
\text { rates minus ECB refinancing } \\
\text { operations rate }\end{array}$ & Bank of Albania and ECB \\
\hline Spread banking rates & $\begin{array}{l}\text { Average interest rate in lek for } 12 \\
\text { month deposits minus average } \\
\text { interest rate in euro for } 12 \text { month } \\
\text { deposits }\end{array}$ & Bank of Albania \\
\hline $\mathrm{E}$ (Depreciation) & $\begin{array}{l}\text { Difference between consensus } \\
\text { forecast exchange rate } 12 \text { month } \\
\text { ahead minus average exchange rate } \\
\text { of the month }\end{array}$ & $\begin{array}{l}\text { Consensus forecast and Bank of } \\
\text { Albania }\end{array}$ \\
\hline
\end{tabular}




\begin{tabular}{|l|l|l|}
\hline E(Inflation) & $\begin{array}{l}\text { Consensus forecast inflation rate 12 } \\
\text { month ahead }\end{array}$ & Consensus forecast \\
\hline Sovereign spread & $\begin{array}{l}\text { Calculated as the yield of eurobond } \\
\text { in non-euro countries over German } \\
\text { bond of the same maturity }\end{array}$ & Bloomberg and IMF staff estimates \\
\hline Inflation & Annual inflation & INSTAT \\
\hline Depreciation & $\begin{array}{l}\text { Annual change in lek per euro } \\
\text { exchange rate }\end{array}$ & Bank of Albania \\
\hline $\begin{array}{l}\text { MVP (Minimum Variance } \\
\text { Portfolio ratio) }\end{array}$ & $\begin{array}{l}\text { This variable measure the strength } \\
\text { of the correlation between inflation } \\
\text { and the real exchange rate } \\
\text { depreciations; variable calculated as } \\
\text { 2 years moving averages (see Ize } \\
\text { and Levy-Yeyati 2003, eq. 9). }\end{array}$ & IMF staff estimates \\
\hline $\begin{array}{l}\text { Risk-free yield curves } \\
\text { Albe government bond yield in }\end{array}$ & Bank of Albania \\
\hline $\begin{array}{l}\text { Net interest margin } \\
\text { Time structure of Lek- } \\
\text { denominated deposits }\end{array}$ & $\begin{array}{l}\text { Net interest margin between deposit } \\
\text { and lending rate for banks in Albania }\end{array}$ & Bank of Albania \\
\hline $\begin{array}{l}\text { Time structure of Lek- } \\
\text { denominated } \\
\text { government securities }\end{array}$ & $\begin{array}{l}\text { Time structure of lek-denominated } \\
\text { government securities }\end{array}$ & Bank of Albania \\
\hline $\begin{array}{l}\text { Composition of Lek- } \\
\text { denominated assets }\end{array}$ & $\begin{array}{l}\text { Composition of lek-denominated } \\
\text { assets }\end{array}$ & Bank of Albania \\
\hline $\begin{array}{l}\text { Structure of all credit to } \\
\text { economy }\end{array}$ & \begin{tabular}{l} 
Structure of all credit to economy \\
\hline
\end{tabular} & Bank of Albania \\
\hline Bimated & Bank of Albania \\
\hline
\end{tabular}




\section{References}

Agarwal, R., and M. Kimball, 2015, "Breaking Through the Zero Lower Bound," Working Paper No. 15/224, International Monetary Fund, Washington, DC.

Bank of Albania, 2018. "Proceedings of the Western Balkan conference on negative euro area policy rates and spillover on Western Balkan central banks policies and instruments," forthcoming.

Basel Committee on Banking Supervision, 2013, Basel III: The Liquidity Coverage Ratio and Liquidity Risk Monitoring Tools, Basel.

Basel Committee on Banking Supervision, 2014, Basel III: The Net Stable Funding Ratio, Basel.

Bech, M. L., and A. Malkhozov, 2016, "How Have Central Banks Implemented Negative Policy Rates?” BIS Quarterly Review (March 2016): 31-44

Borio, C., L. Gambacorta, and B. Hofmann, 2015, "The Influence of Monetary Policy on Bank Profitability," BIS Working Paper No. 514, Bank for International Settlements, Basel, Switzerland.

Broadbent, B., 2014, "Monetary Policy, Asset Prices and Distribution" Speech given at the Society of Business Economists Annual Conference, London, UK, October 23.

El Hamiani Khatat, M., 2018, "Monetary Policy and Models of Current Demand," IMF working paper, Washington, DC, forthcoming.

Calvo, G., and C. Vegh, 1992, "Currency Substitution in Developing Countries: An Introduction,” IMF Working Paper No. 92/40, International Monetary Fund, Washington, DC.

Cassino, V., and P. Misich, 1997, "Forecasting the demand of currency,". Reserve Bank Bulletin, Reserve Bank of New Zealand, 60: 27-33.

De Nicolo, G., P. Honohan, and A. Ize, 2005, "Dollarization of Bank Deposits: Causes and Consequences," Journal of Banking \& Finance 29 (7): 1697-1727.

G. Della Valle, V. Kota, E. Cabezon, R. Veyrune, and S. Guo, 2018, “Euroization in Albania: Drivers and an Effective Policy Response." IMF Working Paper, International Monetary Fund, Washington, DC, forthcoming.

Gesell, S., 1916, "Die Natuerliche Wirtschaftsordnung. Rudolf Zitzman Verlag," Available in English as The Natural Economic Order., London: Peter Owen Ltd, 1958.

Ize, A., and E. Levy Yeyati, 2003, "Financial Dollarization," in Journal of International Economics 59: 323-47. 
Jobst, A., and H. Lin, 2016, "Negative Interest Rate Policy (NIRP): Implications for Monetary Transmission and Bank Profitability in the Euro Area," IMF Working Paper WP/16/172, International Monetary Fund, Washington, DC.

Keynes, J. M., 1936, “The General Theory of Employment, Interest and Money,” London: Macmillan.

Kohli, U., 1987, "A Note on Banknote Characteristics and the Demand for Currency by Denomination," In Journal of Banking and Finance 12 (1988): 389-99.

Mankiw, G., 2009, "It May Be Time for the Fed to Go Negative," New York Times, April 18.

Mougeot, S., 1997, "Demand for Canadian Bank Notes by Denomination: A Combined Share/Regression Approach," Master's diss. (management studies, School of Business, Carleton University, Ottawa, Ontario.

Oesterreichische Nationalbank, 2016, "The euro in Central, Eastern and Southeastern Europe," Vienna, Austria.

Praet, P., 2016. "Monetary Policy and the Euro Area Banking System," Speech at European Capital Markets Institute, Annual Conference, Brussels, November 9, 2016.

Sahay, R., and C. Vegh, 1995, "Inflation and Stabilization in Transition Economies: Comparison with Market Economies," IMF Working Paper 95/8, International Monetary Fund, Washington, DC.

Viñals, J., S. Gray, and K. Eckhold, 2016, "The Broader View: The Positive Effects of Negative Nominal Interest Rates," iMFdirect (April 10), available at https://blogimfdirect. imf.org/2016/04/10/the-broader-view-the-positive-effects-of-negative-nominalinterest-rates/

Walsh, C. E., 2016, "Monetary Theory and Policy,” The MIT Press, Cambridge, Massachusetts. 